\title{
Communal roosting and the seasonal dynamics of the hen harrier Circus cyaneus in the Záhorie region
}

\author{
Nocovanie a sezónna dynamika kane sivej Circus cyaneus na Záhorí
}

\section{Michal NOGA}

\begin{abstract}
A count of hen harriers Circus cyaneus was carried out at roost sites in south-western Slovakia from 1992-2013. The number of sites and also the frequency of survey visits were different in different years. A total of 103 counts were carried out. Hen harriers were not seen roosting at the sites in 13 cases. In all, 10 localities with 14 roost sites were checked. Hen harriers roosted in sedge (5) or in ruderal associations (6) and meadows (3). A total of 634 individuals were recorded roosting. There were 483 brown birds (adult females and immature birds in the first calendar year) and 151 grey birds (males in the second calendar year and older). The average number of hen harriers at the roost sites ranged from 3 to 9 individual birds. The maximum number was at least 27 individuals (December 15, 2011; a minimum of 18 brown birds and 9 grey birds, Moravský Svätý Ján, Pačitov locality). The percentage of roosting males was $23.76 \%$. The time period of roosting was also recorded. The last individuals were observed flying over the site from six minutes before sunset to 40 minutes after sunset. The average time of the last observation was approximately 17 minutes after sunset. The average luminosity at the last observation of an active individual bird was 28 lux. Hen harriers migrate from October to March in the study area. Occurrences in September, respectively in April and May, were very rare. Most registration and the highest number of individual birds were recorded in October, but especially in December and February.
\end{abstract}

\begin{abstract}
Abstrakt: V rokoch 1992-2013 bolo na juhozápadnom Slovensku realizované sčítanie kaní sivých na nocoviskách. Počet lokalít i frekvencia návštev bola v jednotlivých rokoch rozdielna. Kontrolovaných bolo 10 lokalít so 14 miestami nocovania. Spolu bolo realizovaných 103 sčítaní, v 13 prípadoch kane na lokalitách nenocovali. Nocoviská boli v porastoch ostríc (5 lokalít) alebo v ruderálnych spoločenstvách (6 lokalít) a lúkach (3 lokality). Celkovo bolo zaznamenané nocovanie 634 exemplárov, 483 hnedých vtákov (samice a mladé jedince $\mathrm{v}$ prvom kalendárnom roku života) a 151 sivých vtákov (samce v druhom kalendárnom roku a staršie). Priemerný počet kaní na nocoviskách sa pohyboval od 3 do 9 jedincov. Najvyšší zaznamenaný počet bol min. 27 kaní (15. decembra 2011; min. 18 hnedých vtákov a 9 samcov, lokalita Moravský Sv. Ján - Pačitov). Percentuálny pomer nocujúcich samcov bol 23.76\%. Sledovaný bol i časový priebeh zanocovania. Posledné jedince boli nad lokalitou pozorované v rozpätí 6 minút pred západom slnka po 40 minút po západe slnka. Priemerný čas posledného pozorovania bol približne 17 minút po západe slnka. Priemerná svetelnost' pri poslednom pozorovaní aktívneho jedinca bola 28 luxov. Kane sivé sledovaným územím migrujú od októbra do marca. Výskyty v septembri, resp. apríli a máji boli vel'mi zriedkavé. Najviac registrácii i najvyššie počty jedincov bol zistené v októbri, no najmä v decembri a vo februári.
\end{abstract}

Key words: winter roost, crepuscular activity

Michal Noga, Raptor Protection of Slovakia, Kuklovská 5, 84104 Bratislava 4, Slovakia. E-mail: noga@dravce.sk.

Acknowledgments: We would like to thank everyone involved for providing their data, insights and consultation to this paper. In particular, we wish to thank Gašpar Čamlík, David Horal, Hana Latková, Rudolf Jureček, Ján Svetlík, Radovan Václav, Vlasta Škorpíková, Jozef Chavko, Martin Dobrý and Vladimír Nemček. Data on the occurrence of the hen harrier were collected during monitoring supported by the project CORO-SKAT Conservation of Raptors and Owls - Slovakia-Austria in the Slovak-Austrian cross-border cooperation programme 2007-2013, financed by the European Regional Development Fund. We are grateful to Marcel Uhrin for his valuable comments.

\section{Introduction}

Communal roosting in birds is a very special phenomenon which is still paid only marginal research attention. It is something more than just the common aggregation into flocks. It is accompanied by a speci- fic social behaviour, or ethological patterns, and it also has a socioeconomic or epidemiological significance (Stiefel 1976, Chick et al. 1980, Glahn et. al. 1991, Veselovský 2005, Škorpíková \& Horal 2006, Čamlík 2011). 
Communal roosts have been recognised in many species of birds. They are common in aquatic birds (Anseriformes, Ciconiiformes, Laridae) or passerines, especially in corvine species (Corvidae). Night aggregations of roosting individuals are common in flocking species, such as the rook Corvus frugilegus or the gull Larus sp., but also those species that spend the day more or less individually, such as the Eurasian wren Troglodytes troglodytes. Most species spend the night together during the non-breeding season (during migration and wintering), but communal roosting is also known during the breeding season (Stiefel 1976).

Predatory species, such as raptors, gather together at communal roost sites at night, too. This is characteristic for the red kite Milvus milvus or the hen harrier Circus

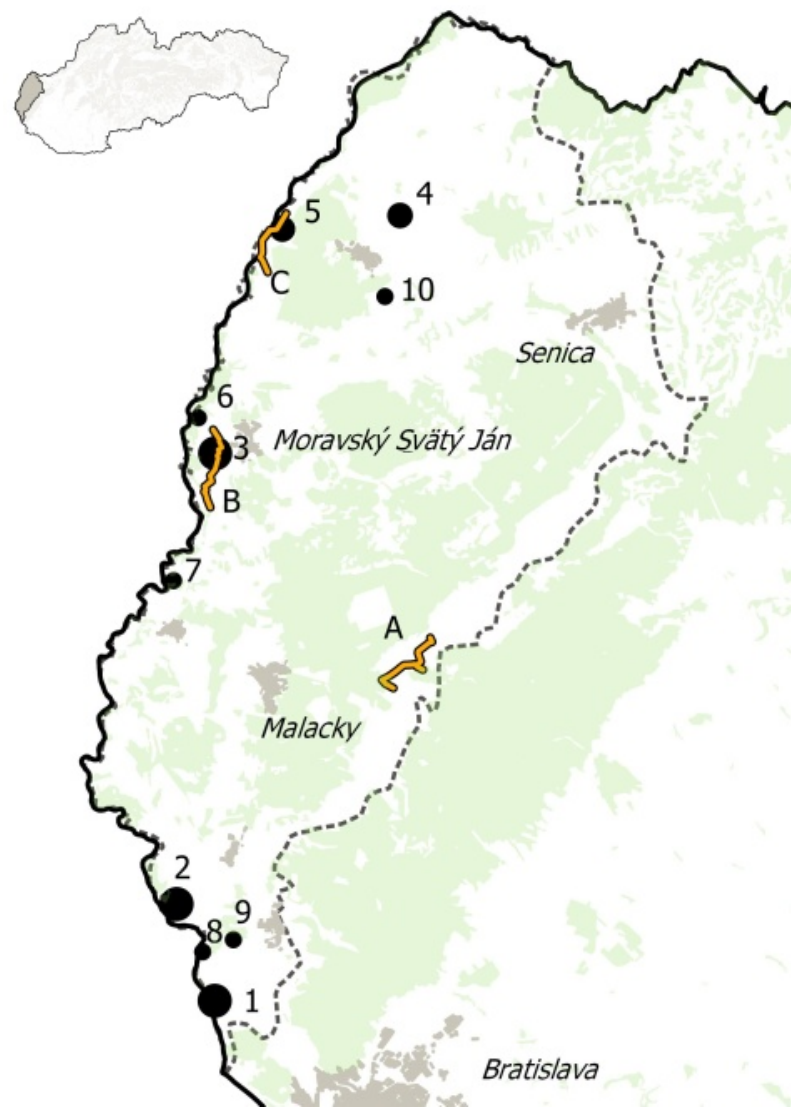

Fig 1. Map of the study area, transects (yellow lines) and the roost sites (regular - large circles, irregular - middle circles and insufficiently checked roost sites - small circles). For site names and numbers see Tab. 1.

Obr. 1. Mapa sledovaného územia, transekty (žlté línie) a nocoviská (pravidelné - vel'ké krúžky, nepravidelné - stredné krúžky a nedostatočne kontrolované nocoviská - malé krúžky). Názvy a čísla lokalít sú uvedené v Tab. 1. cyaneus, the Montagu's harrier C. pygargus and the western marsh harrier C. aeruginosus. Aggregations of eagles are less numerous. Communal roosting is also common in falcons, such as the merlin Falco columbarius, the redfooted falcon Falco vespertinus or the lesser kestrel Falco naumanni (Negro et al. 1991, Clarke 1993, Borbáth \& Zalai 2005, Kitowski 2005, Agošton 2009, Hora et al. 2010).

Only marginal attention has been paid to communal roosting in birds in Slovakia. The data that has been presented are predominantly supplementary data detected from standard surveys (Kaňuščák 2001, Fulín 2009, Maczalová \& Ridzoň 2013). Only the roosting of specific passerine species in nest boxes has been checked (Vel'ký 2002, 2006). There have been published short reports about communal roosting in imperial eagles Aquila heliaca and golden eagles $A$. chrysaetos (Prešinský 2010). Hen harrier roost sites were checked in a different range between 1970 and 2010, particularly in the eastern and western parts of Slovakia (Danko et al. 1995). The hen harrier winters in Slovakia with an estimated population at 3,000-5,500 individuals, though this number can vary considerably. The number of birds at communal roost sites can reach several tens of birds. The maximum number of hen harrier sightings at one site was 185 (Danko 2002). The aim of the present study is to complete the results of hen harrier counts at roost sites in the Záhorie region (SW Slovakia) between 1992 and 2013 and to obtain further details about the time of arrivals and behaviour of this species.

\section{Methods}

S t u d y a r e a

The study was carried out in the Záhorie region, in south-western Slovakia. This area includes the following geomorphological units: the Borská nížina Lowlands, the Chvojnická pahorkatina Upland and the Slovak part of the Dolnomoravský úval Ravine (Fig. 1, Tab. 1).

D a t a c o lle ction

Hen harriers were counted during their evening arrival to the roost site (Tab. 2, Appendix 1). The optimal starting of the survey was half an hour before sunset. The count was finished at least half an hour after sunset. Birds in this study were divided into grey birds and brown birds. Grey birds are males in the second calendar year and older (Génsbol 2008). Brown birds are females and immature birds. It was not possible to determine the exact time of the hen harriers settling at the roosting place because of the frequent flying over 
Tab. 1. Localities - the roost sites (1-10) of hen harriers and transects $(A-C)$ for monitoring the migration and spatial activity of birds of prey (the designation of the locallities is the same as the designation in Fig. 1.)

Tab. 1. Lokality - nocoviská (1-10) kaní sivých a transekty $(A-C)$ na sledovanie migrácie a priestorovej aktivity dravcov (označenie lokalít sa zhoduje s označením v Obr. 1)

\begin{tabular}{|c|c|c|c|}
\hline no. & locality / lokalita & roost type / charakter nocoviska & association type / typ porastu \\
\hline 1 & Devínska Nová Ves, Mäkuša & regular roost site / pravidelné nocovisko & ruderal association / ruderálne spoločenstvo \\
\hline 2 & Devínske jazero & regular roost site / pravidelné nocovisko & $\begin{array}{l}\text { once meadow vegetation, twice the sedge / } \\
1 \times \text { lúčne spoločenstvá, } 2 \times \text { ostrice }\end{array}$ \\
\hline 3 & Moravský Svätý Ján, Pačitov & regular roost site / pravidelné nocovisko & twice the sedge / $2 \times$ ostrice \\
\hline 4 & Petrova Ves & irregular roost site / nepravidelné nocovisko & meadow vegetation / lúčne spoločenstvá \\
\hline 5 & Adamov - Šranky & irregular roost site / nepravidelné nocovisko & ruderal association / ruderálne spoločenstvo \\
\hline 6 & Moravský Svätý Ján, Nemecké & irregular roost site / nepravidelné nocovisko & ruderal association / ruderálne spoločenstvo \\
\hline 7 & Rudavné jazero & irregular roost site / nepravidelné nocovisko & $\begin{array}{l}\text { once the sedge, once ruderal asociation / } \\
1 \times \text { ostrice, } 1 \times \text { ruderálne spoločenstvo }\end{array}$ \\
\hline 8 & Devínske Jazero, železničná stanica & irregular roost site / nepravidelné nocovisko & meadow vegetation / lúčne spoločenstvá \\
\hline 9 & Stupava - Malý háj & irregular roost site / nepravidelné nocovisko & ruderal association / ruderálne spoločenstvo \\
\hline 10 & Smolinské & once checked site / 1 $\times$ kontrolované nocovisko & ruderal association / ruderálne spoločenstvo \\
\hline A & Rohožník & & \\
\hline B & Moravský Svätý Ján & & \\
\hline C & Brodské & & \\
\hline
\end{tabular}

and repeated arrivals and departures of birds from the roost. It was often difficult to determine the exact number of individual birds, especially if only one ornithologist was at the site. For this reason, the numbers presented in this study are the minimum number of roosting hen harriers. There could be more individual birds roosting at the site. The survey was performed from 2007 till 2013. The time of arrivals to the communal roost was monitored. The number of hen harriers sightings at the roost site was recorded at five minute intervals. The luminosity (in lux) was also recorded using a Voltcraft MS-1500. Behaviour, interactions with the vicinity and the weather conditions were also checked during the survey. The count was carried out in monthly intervals from October to March.

Extra information on the seasonal dynamics of the species occurrence was derived from transect research. This was carried out during 2011-2012 (three sites) and during 2012-2013 (one site). At that time all recorded birds of prey were being counted. Transects were $7-10 \mathrm{~km}$ long, and a total of three vantage points were established at each transect. Each point was sampled for 30 minutes. Birds of prey were recorded separately at each counting point and also during their transfer between the points (strip count method). Each count started two and half hours after sunrise. Data on hen harriers were merged into individual months (I.-XII.) because of the comparison of the dynamics of their occurrence. For comparison, the monthly summaries of all hen harrier sightings from the period 1998-2013 are also noted. These data are only informative because
Tab. 2. The number of survey counts of hen harriers conducted in individual years at the checked sites (for locality names and numbers see Tab. 1)

Tab. 2. Počet realizovaných sčítaní kaní v jednotlivých rokoch na sledovaných lokalitách (názvy a čísla lokalít sú uvedené v Tab. 1)

\begin{tabular}{lcccccccccrr}
\hline $\begin{array}{l}\text { year/locality } \\
\text { rok/lokalita }\end{array}$ & $\mathbf{1}$ & $\mathbf{2}$ & $\mathbf{3}$ & $\mathbf{4}$ & $\mathbf{5}$ & $\mathbf{6}$ & $\mathbf{7}$ & $\mathbf{8}$ & $\mathbf{9}$ & $\mathbf{1 0}$ & $\Sigma$ \\
\hline $1992 / 1993$ & & 6 & & & & & & & & & 6 \\
$1994 / 1995$ & & 3 & & & & & & & & & 3 \\
$1995 / 1996$ & & 6 & & & & & & & 4 & & 10 \\
$1996 / 1997$ & & 3 & & & & & & & & & 3 \\
$1997 / 1998$ & & 1 & 1 & & & & & & & & 2 \\
$2004 / 2005$ & & 1 & 4 & & & & 1 & & & 1 & 7 \\
$2005 / 2006$ & & 3 & 5 & 1 & 1 & & 1 & 1 & & & 12 \\
$2006 / 2007$ & & 1 & 7 & 3 & 1 & 2 & & & & & 14 \\
$2007 / 2008$ & 1 & 1 & 5 & & & & & & & & 7 \\
$2008 / 2009$ & 1 & 2 & 1 & & & & & & & & 4 \\
$2010 / 2011$ & & & 3 & & & & & & & & 3 \\
$2011 / 2012$ & 8 & & 7 & 1 & 1 & & & & & & 17 \\
$2012 / 2013$ & 7 & 1 & 6 & 1 & & & & & & & 15 \\
\hline$\Sigma$ & $\mathbf{1 7}$ & $\mathbf{2 8}$ & $\mathbf{3 9}$ & $\mathbf{6}$ & $\mathbf{3}$ & $\mathbf{2}$ & $\mathbf{2}$ & $\mathbf{1}$ & $\mathbf{4}$ & $\mathbf{1}$ & $\mathbf{1 0 1}$ \\
\hline
\end{tabular}

they were obtained using different methods (different frequency of survey visits per month).

The abundance of the main prey of this species (the common vole Microtus arvalis) and a representation of agricultural crops in the surroundings of the roost sites were not checked. The impact of weather on the time of settling was not evaluated because of a very small sample from the counts in bad weather conditions.

\section{Results and discussion}

$\mathrm{S}$ e a s o n a 1 d y a m i c s

Hen harriers occur from September to April in the study area. The earliest records are from the second half of September (September 16, 2011 - the Brodské locality, 
September 30, 2011 - the Kopčany locality). The latest records are from April (April 4, 2008 - the Devínske jazero locality; April 6, 2008 - the Zohor locality; April 22, 2003 - the Gajary locality; April 24, 1993 - the Devínske jazero locality) and rare from May (May 3, 2004 - the Vysoká pri Morave locality). Nesting was not confirmed in the study area (Noga 2005).

Based on results from the transect surveys the highest number of hen harriers in the Záhorie region occurred in December and February. The lower abundance peak was reached in October (Fig. 2).

Differences between months are not so significant if we take into account all the data, i.e. the data derived from the transects ( $\mathrm{n}=51$ observations) and the data obtained by individual observation $(n=107)$ (Fig. 3). This data might not reflect the real time of migration (different number of survey visits per terms), but due to the longer period of time they do illustrate the date range of the hen harrier observations.

Co m m u a 1 roo s t s

During the period 1992-2013, a total of 103 counts of hen harriers were carried out at 10 localities with 14 roost sites. A total of 634 individual birds were recorded in 87 cases. There were 483 brown birds (adult females and immature birds in the first calendar year) and 151 grey birds (males in the second calendar year and older).

The Devínske jazero locality. This locality is situated in the cadastral areas of the village of Vysoká pri Morave, the village of Zohor and the town of Stupava in an area between a river dyke and the Morava River. This is a large complex (1.26 ha) of floodplain meadows (Cnidion venosi communities), and the area is a regular roosting site. Hen harriers rested here at three roost sites located $1.0-1.5 \mathrm{~km}$ apart. In two cases hen harriers roosted in the sedge, in one case in unmowed meadow vegetation. The elevation of the locality is $135 \mathrm{~m}$ above sea level. Part of this area is flooded when there is a high level of groundwater. The maximum number of 18 individual birds was found on October 25, 2008 (14 brown birds, 4 grey birds). The average representation of males (grey birds) during the survey period was $16.58 \%$ of all roosting birds. The wintering and the nesting of the short-eared owl Asio flammeus and the nesting and the roosting of the Montagu's harrier Circus pygargus and the marsh harrier C. aeruginosus were also repeatedly observed at this locality.

The Moravský Svätý Ján, the Pačitov locality. This roost site is situated $2 \mathrm{~km}$ west of the village of Moravský Svätý Ján. Hen harriers were found roosting here in the winter of 1997/1998 for the first time. A count of this species has been carried out annually since the period 2004/2005 (Fig. 4). Hen harriers roost at two sites in the sedge located $470 \mathrm{~m}$ apart. The elevation of this locality is $148 \mathrm{~m}$ above sea level. The locality is partially flooded when there is a high level of groundwater. The maximum number of 27-30 individuals was found on December 15, 2011 (min. 18 brown birds, 9 grey birds). The average representation of males (grey birds) during the survey period was $18.84 \%$ of all roosting birds. The roosting of the marsh harrier Circus aeruginosus and the probable nesting of the short-eared owl Asio flammeus were found at this site.

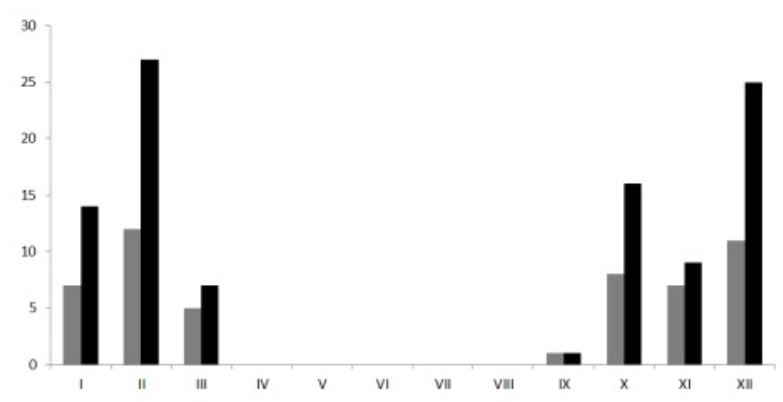

Fig. 2. The seasonal dynamics of the occurrence of hen harriers, results of transects $2010-2013$ ( $n=51$ observations, 99 individuals). Number of observations (grey columns), number of individuals (black columns), $x$ axis - months, $y$ axis - number of observations/number of individuals.

Obr. 2. Sezónna dynamika výskytu kaní sivých, výsledky transektov 2010-2013 ( $n=51$ pozorovaní, 99 jedincov). Počet pozorovaní (sivé stlpce), počet jedincov (čierne stlpce), os $\mathrm{x}$ - mesiace, os $\mathrm{y}$ - počet pozorovaní/počet jedincov.

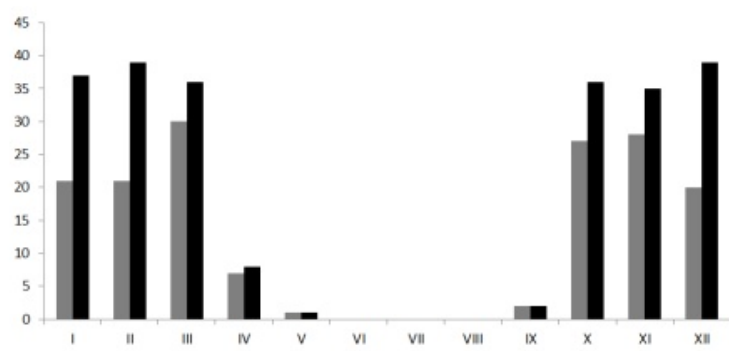

Fig. 3. The seasonal dynamics of the occurrence of hen harriers, all observations 1998-2013 ( $n=157$ observations, 233 individuals). Number of observations (grey columns), number of individuals (black columns), $x$ axis - months, $y$ axis - number of observations/number of individuals.

Obr. 3. Sezónna dynamika výskytu kaní sivých, všetky pozorovania 1998-2013 ( $n=157$ pozorovaní, 233 jedincov). Počet pozorovaní (sivé stĺpce), počet jedincov (čierne stípce), os $\mathrm{x}$ - mesiace, os $\mathrm{y}$ - počet pozorovaní/počet jedincov. 
The Petrova Ves locality. Hen harriers spent the night in meadow vegetation (6.5 ha) situated $3 \mathrm{~km}$ north-west of the village of Petrova Ves. The site was checked during the three winter seasons. In spring 2006, the grassland ( $25 \mathrm{ha}$ ) near the roost site was degraded by ploughing and birds no longer roosted there. The short-eared owls Asio flammeus also winter at this site. The elevation of this locality is $211 \mathrm{~m}$ above sea level. The maximum number of 15 individuals was found on January 17, 2007 (9 brown birds, 7 grey birds). The average representation of males (grey birds) during the survey period was $24.66 \%$ of all roosting birds.

Devínska Nová Ves, the Mäkuša locality. The locality is in the vicinity of the urban district of Bratislava - Devínska Nová Ves. Hen harriers spent the night in ruderal vegetation which passes into periodically flooded sedge vegetation. This roosting site is situated only $7 \mathrm{~km}$ away from the Devínske jazero locality, which is occupied regularly. The elevation of this locality is $140 \mathrm{~m}$ above sea level. The maximum number of $12 \mathrm{in}-$ dividuals was found on February 1, 2012. The average representation of males (grey birds) was relatively high at $36.92 \%$ of all roosting birds.

Other localities. Communal roosting of hen harriers was also recorded at six other sites: the Devínske jazero-the railway station locality; the Stupava-Malý háj locality; the Smolinské locality; the Adamov-Šranky locality, the Malé Leváre-Rudavné jazero locality and the Moravský Svätý Ján-Nemecké locality. These localities were used for roosting irregularly or they were not checked repeatedly. The number of hen harrier sightings did not exceed three individual birds. Exceptions are the Adamov-Šranky locality and the Moravský Svätý Ján-Nemecké locality. At these roosting sites 9-10 hen harriers spent the night.

It is not possible to comment on the proportion of the localities occupied regularly and those occupied irregularly because of the lack of a spatial survey and regular monitoring of all the localities in the Záhorie region. It seems that some of the sites $(33 \%)$ are occupied regularly (the Moravský Svätý Ján locality, the Devínska Nová Ves locality, the Devínske jazero locality) and some (22\%) are occupied irregularly (the Petrova Ves locality, the Adamov locality). The other localities $(45 \%)$ were occupied in only one winter season (the Devínske jazero-the Railway Station locality, the Malé Leváre-Rudavné jazero locality, the Moravský Svätý Ján-Nemecké locality) or they were not checked repeatedly (the Smolinské locality).

During one extensive hen harrier survey undertaken in Britain and Ireland, 212 roosting sites were detected. There were 93 sites occupied regularly (43\%) and 32 were occupied irregularly (14.9\%). It was not possible to rate the rest of the roosts because only a single count was carried out or because only a single roosting of individual birds occurred (Clarke \& Watson 1990).

A r r i vals to the roost $\mathrm{site}$ Hen harriers often stay close to the roost site even during the day. This is probably because of the suitable foraging habitat in its vicinity. Birds often fly over the roost site, then drop and immediately rise again before

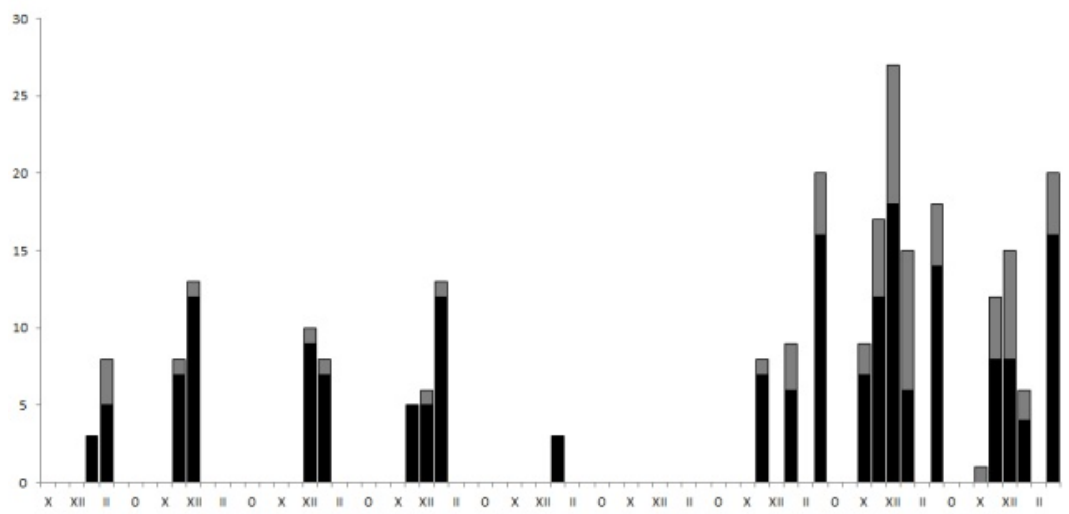

Fig. 4. Changes in abundance of hen harriers at the roost site Moravský Svätý Ján, Pačitov locality in winters 2004/2005-2012/2013; grey columns - number of grey birds, black columns - number of brown birds, $x$ axis - winter months, y axis - number of individuals.

Obr. 4. Zmeny v početnosti kaní sivých na nocovisku Moravský Svätý Ján, Pačitov v zimách 2004/2005 - 2012/2013; sivé stípce počet sivých vtákov, čierne stípce - počet hnedých vtákov, os $\mathrm{x}$ - zimné mesiace, os y - počet jedincov. 


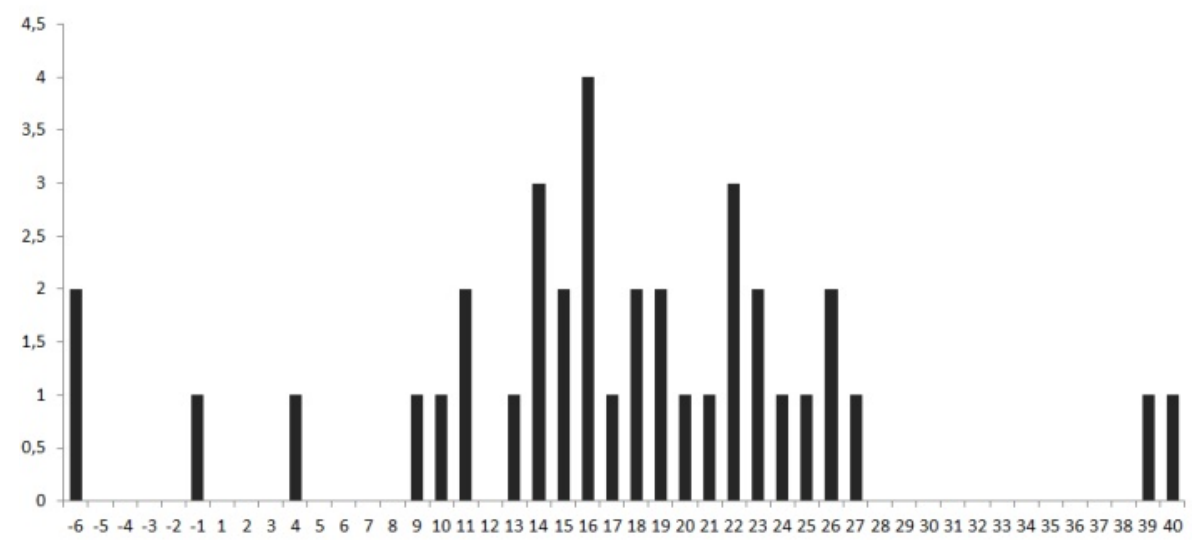

Fig. 5. The time of the last settling of hen harriers at a roost site; $x$ axis - minutes after sunset, $y$ axis - number of cases ( $n=36$ ) Obr. 5. Čas posledného záletu kaní sivých do nocoviska; os $x$ - minúty po západe slnka, os y - počet prípadov ( $n=36)$

settling. For this reason, it is almost impossible to determine the exact time of the beginning of roosting, especially if there is a higher number of individual birds at the roost site. The increased activity of a bird associated with the search for a suitable roost place usually occurs shortly before sunset. The time of roosting was recorded in 36 cases. The last birds flying over the roost site were observed from six minutes before sunset to 40 minutes after sunset (Fig. 5). The average time of the last observation was approximately 17 minutes after sunset. Birds sometimes flew over the wider vicinity before the settling (up to a distance of $500 \mathrm{~m}$ ). This type of behaviour was more often observed in males. Lighting conditions were recorded in 20 cases. The last active birds were observed in 84-6.17 lux. The average value of the last observation was 28 lux. An example of the settle timing is shown in the graph (Fig. 6) (December 31, 2012, the Moravský Svätý Ján-Pačitov locality, 8 immature females, 7 adult males).

Distribution of places for resting within the roost site A resting place in the sedge is a place on the ground among tall vegetation. It is always uncovered from the top. In ruderal associations it is often on a path beaten down by humans or an animal.

The Moravský Svätý Ján-Pačitov (March 3, 2011) and the Devínska Nová Ves-Mäkuša localities (February $21,2014)$ were checked in more detail. The survey was carried out at the end of the winter season in that year.

At the Moravský Svätý Ján-Pačitov locality (0.65 ha) there was homogenous sedge vegetation. Most, respectively, all of the roost sites found $(n=17)$

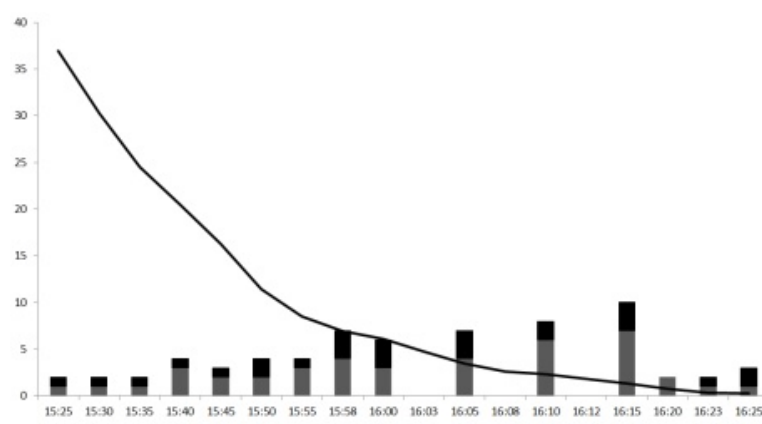

Fig. 6. The time of the settling of hen harriers, the Moravský Svätý Ján locality, December 31, 2012. (x axis - timeline, y axis - number of individuals seen simultaneously; grey columns number of active grey birds, black columns - number of active brown birds; black line - luminosity 3695-0.25 Ix).

Obr. 6. Priebeh aktivity kaní sivých pri zanocovaní, lokalita Moravský Svätý Ján, 31. december 2012 (os x - čas, os y - počet súčasne pozorovaných jedincov; sivé stĺpce - počet aktívnych sivých vtákov, čierne stĺpce - počet aktívnych hnedých vtákov; čierna čiara - svetelnost' 3695-0.25 Ix).

were situated in the area of 0.10 ha $(27 \times 41 \mathrm{~m})$. The shortest distance between two resting places was $0.5-1.0 \mathrm{~m}$. It is possible that these places were used by one bird on different nights. According to the number of pellets found at the places, these places were used repeatedly. A maximum number of 17 pellets were found at one place, and there were usually $3-8$ pellets found at the resting places.

At the Devínska Nová Ves-Mäkuša locality an area of 1.42 ha was checked. A total of 65 resting places used by hen harriers were detected with a total of 162 pellets (Fig. 7). The number of pellets at individual resting 


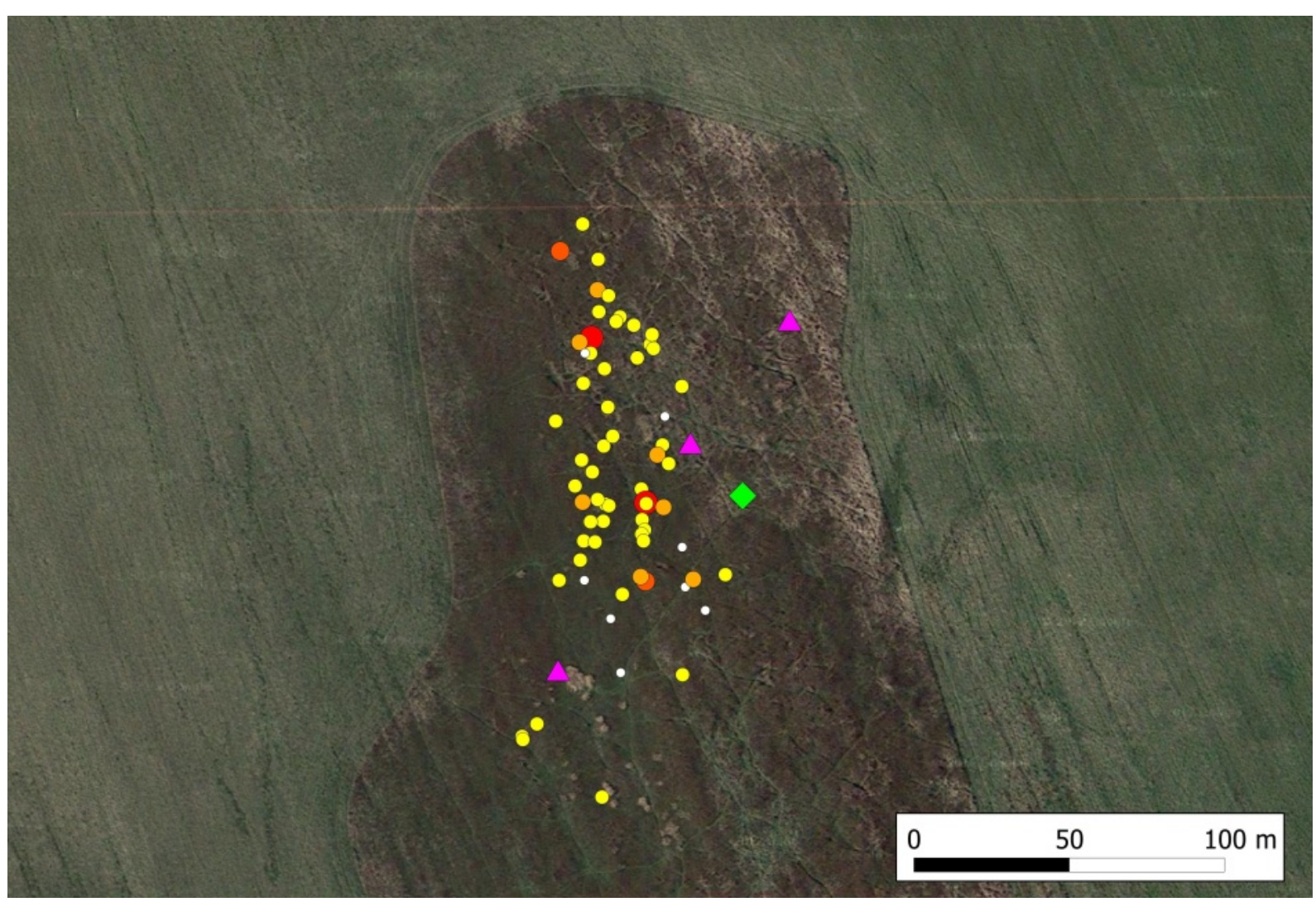

Fig. 7. The distribution of the resting places within the roost site the Devínska Nová Ves-Mäkuša locality. The size and the colour of the circles indicate the number of pellets (white circle -0 pellets, yellow circle $-1-3$ pellets, orange circle $-4-7$ pellets, red circle 8 and more pellets); purple triangle - the roost site of the common pheasant Phasianus colchicus, green diamond: droppings of the red fox Vulpes vulpes.

Obr. 7. Poloha miest odpočinku na nocovisku Devínska Nová Ves - Mäkuša. Vel'kost' a farba krúžkov udáva počet vývržkov (biely kruh - 0 vývržkov, žltý kruh - 1-3 vývržky, oranžový kruh - 4-7 vývržkov, červený kruh - 8 a viac vývržkov; fialový trojuholník: nocovisko Phasianus colchicus, zelený kosoštvorec: trus Vulpes vulpes.

places ranged from 0 to $17(6 \times 0$ pellets, $21 \times 1$ pellet, $18 \times 2$ pellets, $10 \times 3$ pellets, $4 \times 4$ pellets, $3 \times 6$ pellets and $1 \times 7,8,11$ a 17 pellets). The average number of pellets was 2.49 at one place of resting.

The proportion of grey a n d b r o w n bird s

Birds were divided into grey and brown birds during the counts. Grey birds are the males in the second calendar year and older. Brown birds are the females and immature birds. The average representation of grey birds ranged from 16 to $38 \%$ at roosting sites checked over the longterm. Grey birds (males) comprised $23.76 \%$ of all the roosting birds $(\mathrm{n}=88)$. Their average representation ranged from $0 \%$ to $46.54 \%$ in individual years (Fig. 8).

In England, the representation of grey birds ranged from $28.1 \%$ to $45.1 \%$. There was no difference in the proportion of grey birds between winters or months, or between low and high sites. However, there was a striking difference between the eastern and western sites (Clarke \& Watson 1990).

Ethological signs and intera ctions with the vicinity Intra-specific and inter-specific interactions were also recorded during the roost surveys. Hen harriers often chased and followed each other, rarely with a warning calling. An attack by a peregrine falcon Falco peregrinus was observed in one case and an attack by a saker falcon Falco cherrug was observed in two cases. The falcon attacked a hen harrier which was arriving to the roost site. In one case, the attacking saker falcon probably tried to rob the prey in hen harrier's talons. Kleptoparasitism seems to be a frequent hunting strategy of the saker 


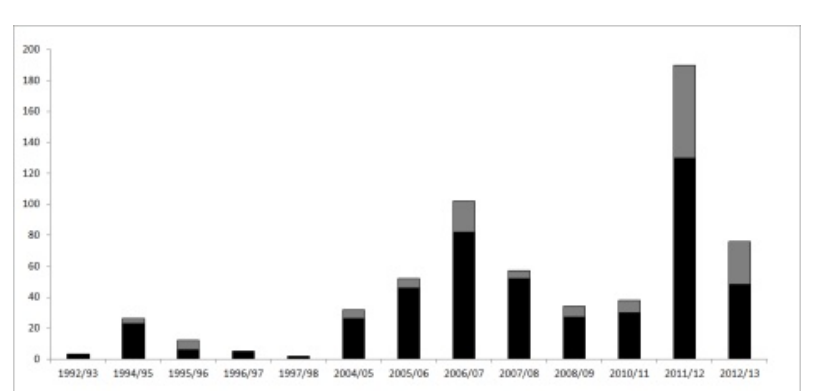

Fig. 8. The proportion of brown birds (black column) and grey birds (grey column) at the roost sites in individual years.

Obr. 8. Pomer hnedých vtákov (čierny stípec) a sivých vtákov (sivý stĺpec) na nocoviskách $v$ jednotlivých rokoch.

falcon (Braun \& Lederer 1996). Hen harriers also become the victims of this type of behaviour from other birds of prey as well (Tunka 2010). Birds ignored the occasional occurrences of the saker falcon and the peregrine falcon as well as common buzzards Buteo buteo, roughlegged buzzards B. lagopus, imperial eagles Aquila heliaca and white-tailed eagles Haliaeetus albicilla. Hen harriers responded very strongly to the presence of the northern goshawk Accipiter gentilis. All of the birds at the roost site flew around it with a warning calling.

A model of the Eurasian eagle-owl Bubo bubo was placed near the roost site (three cases) in order to observe the reaction of the birds. In two cases, birds ignored this model, but in one case they had the same reaction as with the northern goshawk. Hen harriers flew around it and pretended to attack. This behaviour lasted less than a minute. The birds then lost interest and went to roost.

Co-occurrence with short-eared owls was detected at three localities (the Moravský Svätý Ján locality, the Devínske jazero locality and the Petrova Ves locality). Despite the fact that the resting places of individual birds were only 10-30 m apart, no inter-specific interactions were observed. Marsh harriers Circus aeruginosus were found at the same roost site during the survey at the Moravský Svätý Ján locality in September and October (2011), with a maximum number of 9 individuals (September 26, 2011). These birds used the same resting places even after the hen harriers arrived. Both species were roosting together (October 14, 2011 - Circus aeruginosus 3 inds., C. cyaneus 9 inds.). No inter-specific interactions were recorded.

A wing from a dead hen harrier was found at the Moravský Svätý Ján-Pačitov locality in 2011 (approximately $150 \mathrm{~m}$ from the roost site). There is an active burrow of the red fox Vulpes vulpes situated $30 \mathrm{~m}$ from the roost site of hen harriers (at least since 2011). The finding of the wing might not relate to this kind of predator. Red foxes usually do not hunt near their burrows (Škaloud 2009). No significant impact of red foxes on the breeding success of hen harriers in Scotland was found (Green \& Etheridge 1999). Places where droppings of the red fox (resp. canine) and droppings of the common pheasant Phasianus colchicus were found at the hen harriers roost site are shown in the graph (Fig. 6). Hen harriers did not respond to the presence of humans. A warning calling was recorded in only one case. The movement of people was very rare due to time and the remoteness of roost sites, except the Devínska Nová Ves locality. This is in the vicinity of an urban district and it is surrounded by roads on three sides. Its surroundings were often used for walking dogs or other sporting and recreational activities. Despite the frequent movement of people, no escape response of hen harriers and no warning calling or forced leaving of the roost site was recorded. At least 12 of the 65 resting places were found on a path beaten by a human or an animal.

In the Záhorie region there is a high representation of floodplain meadows, marshes, pastures, periodically flooded terrain depressions and ruderal habitats. All of these habitats provide suitable conditions for migration and wintering of hen harriers. A total of 10 localities used by hen harriers were recorded in this region between 1992 and 2013. There were 634 recorded individuals (483 brown birds, 151 grey birds, a ratio of 76:24). The numbers of roosting birds ranged from 12 (the Devínska Nová Ves-Mäkuša locality) to 18 (the Devínske jazero locality), resp. 27 individual birds (the Moravský Svätý Ján locality) at the most important roost sites.

\section{References}

Agošton A 2009: Noćilište sivih vetrušaka Falco vespertinus kod Mokrina [Roosting site of red-footed falcons Falco vespertinus near Mokrin]. Ciconia 18: 197-198. [In Serbia with English summary].

Borbáth P \& Zalai T 2005: Post-nuptial gathering of red-footed falcons (Falco vespertinus) on the Hevesik-sík, Hungary. Aquila 112: 39 - 44.

Braun B \& Lederer E 1996: Kleptoparasitismus eines Würgfalken (Falco cherrug) an Rohrweihen (Circus aeruginsus). Egretta 39: 116.

Clarke R \& Watson D 1990: The hen harrier Circus cyaneus winter roost survey in Britain and Ireland. Bird Study 37: 80-100.

Clarke R 1993: Merlin (Falco columbarius) winter roosts and diet in Britain and Northern France. 178-184. In: Nicholls M-K \& Clarke R (eds): Bio- 
logy and conservation of small falcons. Hawk and Owl Trust, London, 250.

Čamlík G 2011: Hromadná nocovište špačků obecných (Sturnus vulgaris) v podmínkách jižní Moravy. Mokrina [Communal roosting of the common starling Sturnus vulgaris in southern Moravia. Mokrina]. Thesis. Comenius University, Bratislava, 107. [In Czech with Slovak summary]

Danko Š 2002: Kaňa sivá (Circus cyaneus) [The hen harrier Circus cyaneus], 180-182. In: Danko A, Darolová A \& Krištín A (eds): Rozšírenie vtákov na Slovensku. Veda, Bratislava, 668. [In Slovak with English summary]

Danko Š, Chavko J \& Karaska D 1995: Správa o činnosti Skupiny pre ochranu dravcov a sov Slovenskej ornitologickej spoločnosti za rok 1993. [Report on the activities of the Group for the protection of raptors and owls of the Slovak Ornithological Society 1993] Buteo 7: 109-121. [In Slovak with English summary]

Fulín M 2009: Nocovisko pinky severskej v Gelnici [Roosting of brambling in Gelnica]. Vtáky 4(1): 7. [In Slovak]

Génsbol B 2008: Birds of prey. Harper Collins Publishers Ltd. London. 414.

Green RE \& Etheridge B 1999: Breeding success of the hen harrier Circus cyaneus in relation to distribution of grouse moors and the red fox Vulpes vulpes. Journal of applied ecology 36: $472-483$.

Glahn JF, Stickley AR, Heisterberg JF \& Mott DF 1991: Impact of roost control on local urban and agricultural blackbird problems. Wildlife society bulletin 19 : 511-522.

Hora J, Brinke T, Vojtěchovská E, Hanzal V \& Kučera $Z$ (eds) 2010: Monitoring druhů př́lohy I směrnice o ptácích a ptačích oblastí v letech 2005-2007 [Monitoring of species of Annex I of BirdDirective in 2005-2007]. Agentura ochrany prírody a krajiny ČR, Praha, 320. [In Czech]

Chick EW, Flanigan C, Compton SB, Pass T III, Gayle C, Hernandes C, Pitzer FR \& Austin EJr 1980: Blackbird roost and histoplasmosis; and increasing medical problem? Chest 77: $584-585$.

Kaňuščák P 2001: Údaje o t’ahu, zimovaní a dlhodobom mieste nocovania holubov plúžikov (Columba oenas) v širšom okolí Pieštan (západné Slovensko) [Data about migration, wintering and long term roosting of stock doves (Columba oenas) in wider surroundings of Pieštany town (west Slovakia]. Tichodroma 14: 61-66. [In Slovak with English summary]
Kitowski I 2005: Behaviour of hen harrier on communal roost in East Poland. Berkut. 14 (2). 2005. 214-220.

Maczalová M \& Ridzoň J 2013: Nocovisko kormoránov malých v Čuňove v zime 2012/2013 [Roosting of pygmy cormorant in Čunovo in winter 2012/2013]. Vtáky 8(2): 4-5. [In Slovak]

Negro JJ, Riva M \& Bustamante Ch 1991: Patterns of winter distribution and abundance of lesser kestrels (Falco naumanni) in Spain. Journal of Raptor Research 25(2): $30-35$.

Noga M 2005: Hniezdila na Záhorí v roku 2002 kaňa sivá (Circus cyaneus) [Did the hen harrier Circus cyaneus breed in the Záhorie region in 2002]? Crex 25: 140-142. [In Slovak with English summary]

Prešinský L 2010: Šliapanie na vrchol (z denníka dravčiara) [Walking to summit (from the field diary)]. Dravce a sovy 6(1): 29 - 30. [In Slovak with English summary]

Tunka Z 2010: Zimní chování dravců. Zajímavé lovecké taktiky dravců v zimě 2009/2010 na Znojemsku. [Winter behaviour of birds of prey. Intereresting hunting tactics of birds of prey in Znojmo region in winter 2009/2010] Crex 30: 145-150. [In Czech with English summary].

Vel'ký M 2006: Vzt’ahy medzi využívaním búdok vtákmi v zimnom a hniezdnom období [Patterns in winter-roosting and breeding of birds in nest-boxes]. Tichodroma 18: 89-96. [In Slovak with English summary]

Veselovský Z 2005: Etologie. Biologie chování zvírat [Ethology. Animal behaviour biology]. Academia, Praha, 408. [In Czech]

Stiefel A 1971: Ruhe und Schlaf bei Vogeln [Die Neue Brehm-Bucherei 487]. A. Ziemsen Verlag, Wittenberg Lutherstadt. 213.

Škaloud V 2009: Liška a větší šelmy [Fox and larger predators]. Nakladatelství Brázda. Praha. 259. [In Czech]

Škorpíková V \& Horal D 2006: Společná nocoviště špačka obecného (Sturnus vulgaris) a odhad jeho přibližné početnosti ve vinařských oblastech Jihomoravského kraje v záŕí - říjnu 2005. [Common roosting places of the starling (Sturnus vulgaris) and estimate of its numbers in vineyard regions of South Moravia in September - October 2005]. Crex 26: 126-130. [In Czech with English summary]

Vel'ký M 2002: Zimovanie a nocovanie vtákov v búdkach $\mathrm{v}$ mestskom prostredí [Wintering and roosting of birds in nest boxes in urban environment]. Tichodroma 15: 60-70. [In Slovak English summary] 
Appendix 1. Results of the count of hen harriers at the roost sites 1992-2013

Appendix 1. Výsledky sčítaní kaní sivých na nocoviskách, 1992-2013

\begin{tabular}{|c|c|c|c|c|}
\hline date / dátum & $\mathbf{F}$ & M & $\Sigma$ & observer / pozorovatel' \\
\hline \multicolumn{5}{|c|}{ Devínske jazero } \\
\hline 25. 10. 1992 & 0 & 0 & 0 & Chavko \& Tomovčík \\
\hline 29. 11. 1992 & 1 & 0 & 1 & Chavko \& Tomovčík \\
\hline 20. 12. 1992 & 0 & 0 & 0 & Chavko \& Tomovčík \\
\hline 17. 1. 1993 & 0 & 0 & 0 & Chavko \& Tomovčík \\
\hline 21. 2. 1993 & 1 & 0 & 1 & Chavko \& Tomovčík \\
\hline 21. 3. 1993 & 1 & 0 & 1 & Chavko \& Tomovčík \\
\hline 15. 1. 1995 & 8 & 2 & 10 & Noga \\
\hline 19. 2. 1995 & 12 & 0 & 12 & Noga \\
\hline 19. 3. 1995 & 3 & 1 & 4 & Noga \\
\hline 22. 10. 1995 & 0 & 0 & 0 & Noga \\
\hline 17. 12. 1995 & 0 & 0 & 0 & Noga \\
\hline 14. 1. 1996 & 2 & 0 & 2 & Noga \\
\hline 18. 2. 1996 & 2 & 0 & 2 & Noga \\
\hline 23. 2. 1996 & 0 & 0 & 0 & Noga \\
\hline 17. 3. 1996 & 1 & 0 & 1 & Noga \\
\hline 20. 10. 1996 & 4 & 0 & 4 & Noga \\
\hline 24. 11. 1996 & 1 & 0 & 1 & Noga \\
\hline 15. 12. 1996 & 0 & 0 & 0 & Noga \\
\hline 26. 10. 1997 & 0 & 0 & 0 & Noga \\
\hline 17. 1. 2005 & 3 & 1 & 4 & Noga \\
\hline 9. 11. 2005 & 1 & 3 & 4 & Čamlík \\
\hline 23. 11. 2005 & 0 & 1 & 1 & Čamlík \\
\hline 17. 1. 2006 & 3 & 1 & 4 & Latková \\
\hline 20. 10. 2006 & 4 & 0 & 4 & Noga \\
\hline 26. 1. 2008 & 12 & 0 & 12 & Noga \\
\hline 19. 10. 2008 & 4 & 1 & 5 & Noga \\
\hline 25. 10. 2008 & 14 & 4 & 18 & Noga \\
\hline 24. 11. 2012 & 1 & 1 & 2 & Noga \\
\hline \multicolumn{5}{|c|}{ Moravský Svätý Ján, Pačitov } \\
\hline 15. 2. 1998 & 2 & 0 & 2 & Noga \\
\hline 19. 12. 2004 & 6 & 0 & 6 & Čamlík \& Kal'avský \\
\hline 15. 1. 2005 & 3 & 0 & 3 & Noga \\
\hline 29. 1. 2005 & 8 & 0 & 8 & Čamlík \\
\hline 20. 2. 2005 & 5 & 3 & 8 & Noga \\
\hline 6. 11. 2005 & 2 & 0 & 2 & Čamlík \\
\hline 14. 11. 2005 & 7 & 1 & 8 & Noga \\
\hline 27. 11. 2005 & 9 & 0 & 9 & Čamlík \\
\hline 4. 12. 2005 & 12 & 1 & 13 & Noga \\
\hline 19. 3.2006 & 7 & 0 & 7 & Čamlík \\
\hline 31. 10. 2006 & 1 & 1 & 2 & Čamlík \\
\hline 26. 11. 2006 & 1 & 0 & 1 & Čamlík \\
\hline 18. 12. 2006 & 2 & 0 & 2 & Čamlík \\
\hline 23. 12. 2006 & 9 & 1 & 10 & Noga \\
\hline 31. 12. 2006 & 7 & 1 & 8 & Noga \\
\hline 13. 1. 2007 & 9 & 0 & 9 & Noga \\
\hline 11. 2. 2007 & 4 & 0 & 4 & $\begin{array}{l}\text { Čamlík, Venturová } \\
\text { \& Kal'avský }\end{array}$ \\
\hline 18. 11. 2007 & 5 & 0 & 5 & Noga \\
\hline 9. 12. 2007 & 7 & 1 & 8 & Čamlík \\
\hline 15. 12. 2007 & 5 & 1 & 6 & $\begin{array}{l}\text { Noga, Čamlík, Horal, } \\
\text { Štěpánek, Berka } \\
\text { \& Severa }\end{array}$ \\
\hline 19. 12. 2007 & 7 & 1 & 8 & Noga \\
\hline 12. 1. 2008 & 12 & 1 & 13 & Noga \\
\hline 17. 1. 2009 & 3 & 0 & 3 & Noga \\
\hline 17. 11. 2010 & 8 & 1 & 9 & Noga \\
\hline 15. 1. 2011 & 6 & 3 & 9 & Noga \\
\hline 5. 3. 2011 & 16 & 4 & 20 & Noga \\
\hline
\end{tabular}

\begin{tabular}{|c|c|c|c|c|}
\hline date / dátum & $\mathbf{F}$ & M & $\Sigma$ & observer / pozorovatel' \\
\hline 14. 10. 2011 & 7 & 2 & 9 & Noga \\
\hline 11. 11.2011 & 6 & 5 & 11 & Noga \\
\hline 28. 11. 2011 & 12 & 5 & 17 & Noga \\
\hline 13. 12. 2011 & 9 & 4 & 13 & Noga \\
\hline 15. 12.2011 & 18 & 9 & 27 & $\begin{array}{l}\text { Noga, Horal, Bělka } \\
\text { \& Mikusek }\end{array}$ \\
\hline 25. 1. 2012 & 6 & 9 & 15 & Noga \\
\hline 3. 3. 2012 & 14 & 4 & 18 & Noga \\
\hline 21. 9. 2012 & 0 & 0 & 0 & Noga \\
\hline 19. 10. 2012 & 0 & 1 & 1 & Noga \\
\hline 28. 11. 2012 & 8 & 4 & 12 & Noga \\
\hline 31. 12. 2012 & 8 & 7 & 15 & Noga \\
\hline 31. 1. 2013 & 5 & 2 & 7 & Noga \\
\hline 4. 3. 2013 & 16 & 4 & 20 & Noga \\
\hline \multicolumn{5}{|l|}{ Petrova Ves } \\
\hline 19. 3. 2006 & 2 & 0 & 2 & Noga \\
\hline 16. 11.2006 & 6 & 3 & 9 & Noga \\
\hline 26. 11. 2006 & 9 & 3 & 12 & Noga \\
\hline 17. 1. 2007 & 9 & 6 & 15 & Noga \\
\hline 6. 3. 2012 & 3 & 1 & 4 & Noga \\
\hline 27. 11. 2012 & 0 & 0 & 0 & Noga \\
\hline \multicolumn{5}{|c|}{ Devínska Nová Ves - Mäkuša } \\
\hline 1. 3.2008 & 4 & 1 & 5 & Noga \\
\hline 1. 11. 2008 & 6 & 2 & 8 & Noga \\
\hline 12. 12.2011 & 4 & 2 & 6 & Noga \\
\hline 22. 1. 2012 & 8 & 3 & 11 & Noga \\
\hline 23. 1. 2012 & 6 & 3 & 9 & Noga \\
\hline 1. 2. 2012 & 9 & 3 & 12 & Noga \\
\hline 14. 2. 2012 & 7 & 4 & 11 & Noga \\
\hline 24. 2. 2012 & 6 & 2 & 8 & Noga \\
\hline 27. 2. 2012 & 1 & 2 & 3 & Noga \\
\hline 5. 3. 2012 & 5 & 2 & 7 & Noga \\
\hline 24. 10. 2012 & 0 & 0 & 0 & Noga \\
\hline 24. 11. 2012 & 1 & 1 & 2 & Noga \\
\hline 13. 12. 2012 & 2 & 2 & 4 & Noga \\
\hline 30. 12. 2012 & 4 & 4 & 8 & Noga \\
\hline 27. 2. 2013 & 2 & 1 & 3 & Noga \\
\hline 29. 3. 2013 & 1 & 1 & 2 & Noga \\
\hline 26. 10. 2013 & 0 & 0 & 0 & Noga \\
\hline \multicolumn{5}{|c|}{ Adamovské štrkoviská } \\
\hline 11. 1. 2006 & 0 & 1 & 1 & Noga \\
\hline 26. 1. 2007 & 8 & 0 & 8 & Čamlík \\
\hline 16. 12. 2011 & 9 & 0 & 9 & Horal \& Čamlík \\
\hline \multicolumn{5}{|c|}{ Stupava - Malý háj } \\
\hline 22. 10. 1995 & 0 & 2 & 2 & Noga \\
\hline 26. 11. 1995 & 0 & 3 & 3 & Brinzík \& Popovič \\
\hline 15. 1.1996 & 1 & 0 & 1 & Noga \\
\hline 18. 2. 1996 & 0 & 1 & 1 & Noga \\
\hline \multicolumn{5}{|c|}{ Rudavné jazero } \\
\hline 16. 1. 2005 & 0 & 0 & 0 & Noga \\
\hline 26. 2. 2006 & 3 & 0 & 3 & Čamlík \\
\hline \multicolumn{5}{|c|}{ Moravský Svätý Ján, Nemecké } \\
\hline 19. 12. 2006 & 5 & 3 & 8 & Čamlík \\
\hline 23. 12. 2006 & 8 & 2 & 10 & $\begin{array}{l}\text { Noga, Štěpánek, Krejčí } \\
\text { Venturová \& Čamlík }\end{array}$ \\
\hline \multicolumn{5}{|c|}{ Devínske Jazero, žel. Stanica } \\
\hline 27. 11. 2005 & 3 & 0 & 3 & Latková \& Kal'avský \\
\hline \multicolumn{5}{|l|}{ Smolinské } \\
\hline 14. 1. 2005 & 1 & 2 & 3 & Noga \\
\hline
\end{tabular}

